\title{
PELATIHAN DESAIN GRAFIS CORELDRAW MENINGKATKAN KREATIVITAS KARANG TARUNA PEMUDA MANDIRI KELURAHAN REJOMULYO
}

Diterima: 01 Januari 2021 ｜ Direview: 12 Januari 2021 | Disetujui: 07 Februari 2021

\author{
Meyta Pritandhari ${ }^{1}$, Fajri Arif Wibawa ${ }^{2}$ \\ Universitas Muhammadiyah Metro, Jl. Ki Hajar Dewantara, 34111, Lampung, Indonesia \\ Email: meyta.pritandhari@gmail.com
}

\begin{abstract}
ABSTRAK
Dalam era milenial dan digital saat ini, dunia desain mengalami perkembangan yang sangat pesat. Dalam hal ini, khususnya generasi muda perlu dibekali ilmu tentang desain grafis. Pelatihan ini dilakukan di lembaga masyarakat yaitu karang taruna. Karang Taruna Pemuda Mandiri Kelurahan Rejomulyo adalah salah satu Lembaga Kemasyarakatan yang merupakan wadah pengembangan generasi muda yang tumbuh dan berkembang atas dasar kesadaran dan rasa tanggung jawab sosial. Pengurus Karang Taruna Pemuda Mandiri mayoritas adalah pemuda yang masih produktif. Pelatihan untuk meningkatkan kreativitas Karang Taruna Pemuda Mandiri khususnya pada kemampuan desain grafis CorelDRAW guna meningkatkan kreatifitas . Kemampuan dalam menyampaikan ide dan gagasan dalam upaya untuk membangun generasi muda melalui kreativitas karang taruna tentu memerlukan dukungan teknologi informasi dan komunikasi yang dituangkan dalam bentuk spanduk, poster, undangan. Ini semua dapat dilakukan, jika kita dapat menguasai atau memiliki kemampuan desain grafis yang baik. Pada kesempatan kali ini akan dilakukan transfer pengetahuan berupa penguasaan ketrampilan desain grafis menggunakan CorelDRAW.
\end{abstract}

Kata Kunci: CorelDRAW, Kreativitas, Karang Taruna

\begin{abstract}
In today's millennial and digital era, world design is experiencing very rapid development. In this case, especially the younger generation needs to be equipped with knowledge about graphic design. This training is conducted in community institutions, namely youth organizations. Youth Organization Youth Organization Rejomulyo Village is one of the Community Institutions which is a forum for youth development that grows and develops on the basis of awareness and a sense of social responsibility. The board of the Youth Youth Organization for Youth is still productive youth. Training to increase the creativity of the Youth Youth Organization especially in CorelDRAW graphic design skills to increase creativity. The ability to convey ideas and ideas in an effort to build a young generation whose creativity certainly requires the support of information and communication technology as outlined in the form of banners, posters, invitations. This can all be done, if we can master or have good graphic design skills. On this occasion, there will be a transfer of knowledge in the form of mastery of graphic design skills using CorelDRAW.
\end{abstract}

Keywords: CorelDRAW, Creativity, Karang Taruna

\section{PENDAHULUAN}

Teknologi informasi telah berkembang sedemikian pesatnya, menjadikan segala sesuatunya menjadikan lebih mudah. Segala aktifitas kita banyak ditunjang dengan teknologi tersebut. Dalam kesempatan ini, pengabdian kepada masyarakat ini dilakukan di Karang 
Taruna Pemuda Mandiri, Kelurahan Rejomulyo Kecamatan Metro Selatan Kota Metro. Para pengrus Karang Taruna Pemuda Mandiri akan diberi pengetahuan tentang pemanfaatan software pengolah grafis untuk kepentingan dan kegiatan - kegiatan yang membutuhkan pengolahan grafis dan foto. Diharapkan dari kegiatan pelatihan yang dilakukan ini dapat memberikan manfaat bagi para pengurus karang taruna untuk meningkatkan kreatifitasnya khususnya dalam bidang desain grafis. Hal tersebut diperkuat dengan Wahyudi dan Anggri (2020) yang mengemukakan bahwa teknologi informasi telah berkembang sedemikian pesatnya, menjadikan segala sesuatunya menjadikan lebih mudah, segala aktifitas kita banyak ditunjang dengan teknologi tersebut.

Banyaknya kalangan remaja di lingkungan mitra yang memiliki kreatifitas dalam menggambar, tetapi mereka mamanfaatkan media yang tidak sewajarnya. Mereka juga belum memiliki pengetahuan tentang aplikasi atau software untuk mendesain gambar. Agar lingkungan tidak tercemar, dan kalangan remaja tersebut dapat menuangkan ide kreatif mereka kedalam bentuk digital. Kesulitan pengurus karang taruna dalam pemanfaatan software pengolah vector untuk pembuatan banner, spanduk untuk mendukung berbagai acara yang diselenggarakan oleh desa dan membuat media komunikasi yang menarik antara pengurus karang taruna dengan masyarakat. Menjawab permasalahan tersebut perlu adanya peningkatkan diri dengan berbagai macam cara antara lain dengan pelatihan. Pelatihan untuk memanfaatkan software pengolah vektor dapat meningkatkan kemampuan dari perangkat desa untuk lebih kreatif dalam memanfaatkan media tersebut sebagai alat komunikasi yang menarik.

Berdasarkan Pasal 1 angka 14 Peraturan Menteri Dalam Negeri No. 5 Tahun 2007 tentang Pedoman Penataan Lembaga Kemasyarakatan karang taruna adalah Lembaga Kemasyarakatan yang merupakan wadah pengembangan generasi muda yang tumbuh dan berkembang atas dasar kesadaran dan rasa tanggung jawab sosial dari, oleh dan untuk masyarakat terutama generasi muda di wilayah desa/kelurahan atau komunitas adat sederajat dan terutama bergerak di bidang usaha kesejahteraan sosial, yang secara fungsional dibina dan dikembangkan oleh Departemen Sosial. Dalam hal ini Karang Taruna Pemuda Mandiri mayoritas adalah pemuda yang masih produktif. Dengan memberdayakan pengurus Karang Taruna Pemuda Mandiri diharapkan dapat memajukan generasi pemuda dibawah organisasi karang taruna yang mampu meningkatkan keterampilan dibidang desain grafis CorelDRAW. Seiring dengan perkembangan zaman era industri 4.0 yang menuntut semua masyarakat khususnya pemuda agar dapat mengakses informasi dan aktivitas secara online, maka 
diperlukan persiapan untuk meningkatkan kemampuan dan keterampilan yang diperkuat dengan desain grafis CorelDRAW yang lebih sesuai dengan zamannya. Karang Taruna Pemuda Mandiri mayoritas adalah pemuda yang masih produktif. Dengan memberdayakan pengurus Karang Taruna Pemuda Mandiri diharapkan dapat memajukan generasi pemuda dibawah organisasi karang taruna yang mampu meningkatkan kreatifitas dibidang desain grafis CorelDRAW.

Pelatihan adalah suatu proses pembelajaran yang memperbanyak praktek dibandingkan teori yang dilakukan pelatih secara mendiri ataupun berkelompok untuk meningkatkan kemampuan dari individu ataupun kelompok. Tujuan dari pelatihan adalah individu maupun kelompok yang dilatih mempunyai penguasaan ketrampilan yang dapat dikuasai. Jenis pelatihan ada pelatihan wacana, ketrampilan, dan soft skill. Sedangkan cirri pelatihan antara lain terdapatnya suatu proses untuk meningkatkan ketrampilan yang dimiliki, materi yang disampaikan merupakan ketrampilan tertentu yang diperlukan, pelatihan dalam jangka waktu tertentu, dan proses pelatihannya dilakukan dengan mempelajari dan mempraktekkan sehingga menjadi kebiasaan (Santoso, dalam Endah dan Aulia, 2018).

Kegiatan pelatihan sangat penting karena bermanfaat guna menambah pengetahuan atau keterampilan terutama bagi yang mempersiapkan diri memasuki lapangan pekerjaan (Anggun dalam Sony, 2019). Beberapa manfaat yang diperoleh dari program pelatihan diantaranya adalah (Simamora dalam Sony, 2019): 1) Meningkatkan kualitas dan kuantitas produktivitas. 2) Mengurangi waktu belajar yang diperlukanuntuk mencapai standar kinerja yang dapat diterima. 3) Membentuk sikap, loyalitas, dan kerjasama yang lebih menguntungkan. 4) Memenuhi kebutuhan perencanaan sumber daya manusia. 5) Mengurangi frekuensi dan biaya kecelakaan kerja. 6) Membatu dalam peningkatan dan pegembangan pribadi mereka. Hal tersebut juga diperkuat Rini dan Dodit (2018) yang menjelasakan bahwa pelatihan untuk membuat desain grafis menjadi hal yang dirasa sangat perlu untuk menigkatkan kreatifitas warga masyarakat yang ikut terlibat dalam kegiatan secara bersama-sama.

Corel Draw merupakan program pengolah desain grafis yang familier dan paling diminati di kalangan desain grafis. Program ini dapat digunakan dengan mudah karena terdapat tool-tool maupun efek yang menghasilkan berbagai bentuk desain yang inovatif dan ekspresif dengan dilengkapi komposisi warna yang bagus, serta adanya tool untuk membuat objek yang unik dan kreatif. Desain grafis atau rancang grafis adalah proses komunikasi menggunakan elemen visual, seperti tulisan, bentuk, dan gambar yang dimaksudkan untuk menciptakan 
persepsi akan suatu pesan yang disampaikan.Desain grafis pada awalnya diterapkan untuk media-media statis, seperti buku, majalah, dan brosur. Sebagai tambahan, sejalan dengan perkembangan zaman, desain grafis juga diterapkan dalam media elektronik, yang sering kali disebut sebagai desain interaktif atau desain multimedia.Batas dimensi pun telah berubah seiring perkembangan pemikiran tentang desain. Desain grafis bisa diterapkan menjadi sebuah desain lingkungan yang mencakup pengolahan ruang (Suparno dalam Endah dan Aulia, 2018).

CorelDraw adalah salah satu aplikasi yang menunjang kegiatan dari segi design grafis. Tidak hanya aplikasi perkantoran seperti Office yang dibutuhkan untuk menunjang kegiatan. Unsur dalam desain grafis sama seperti unsur dasar dalam disiplin desain untuk berbagai keperluan kegiatan (Mayang, 2016). Unsur-unsur tersebut (termasuk shape, bentuk (form), tekstur, garis, ruang, dan warna) membentuk prinsip-prinsip dasar desain visual. Prinsipprinsip tersebut, seperti keseimbangan (balance), ritme (rhythm), tekanan (emphasis), proporsi (proportion) dan kesatuan (unity), kemudian membentuk aspek struktural komposisi yang lebih luas.

Dalam desain grafis tentu perlu melakukan praktik beberapa kali agar dapat mahir. Dalam Ridwan dkk (2020) kemampuan peserta pelatihan dalam memahami desain grafis peserta cukup baik, ini ditunjukan dengan kemampuan peserta dalam mengingat jenis dan letak tools yang digunakan sesuai dengan kebutuhan. Kemudian kemampuan teknis praktik peserta masih memerlukan latihan secara rutin terutama dalam kemampuan memodifikasi bentuk umum yang telah tersedia dari aplikasi menjadi bentuk-bentuk yang sesuai dengan keinginan.

Permasalahan yang terjadi pada mitra adalah (1) Hampir semua pengurus Karang Taruna Pemuda Mandiri kurang mengenal desain grafis CorelDRAW, (2) Kurangnya kesadaran pengurus Karang Taruna Pemuda Mandiri akan pentingnya penguasaan desain grafis CorelDRAW dalam menunjang kegiatan karang taruna, (3) Sebagian besar pengurus Karang Taruna Pemuda Mandiri mampu mengoperasikan leptop/komputer dan memiliki potensi dalam untuk dapat bisa menguasai desain grafis CorelDRAW, namun belum dapat memaksimalkan sebagai penunjang kegiatan Karang Taruna Pemuda Mandiri.

Sehingga dapat meningkatkan keefektifan berbagai kegiatan Karang Taruna Pemuda Mandiri. Kegiatan pengabdian yang dilakukan kepada mitra berupa pengembangan keterampilan desain grafis menggunakan aplikasi CorelDRAW pada pengurus Karang Taruna Pemuda Mandiri Kelurahan Rejomulyo Kota Metro. Rais dkk (2018) Software CorelDRAW digunakan rata-rata untuk membuat garis-garis vector, Contohnya logo. Dengan kelengkapan 
tools dari software ini, juga controlnya pun lebih nyaman, mendesain logo vector menjadi lebih mudah. Begitu pesat berkembangnya teknologi komputer, yang terutama pada perangkat lunak, mau tidak mau kita juga harus mengikuti perkembangannya.

Untuk menjawab permasalahan yang dihadapi mitra dan merealisasikan solusinya, maka direncanakan untuk melakukan beberapa kegiatan yaitu: (1) Persiapan: pada tahap ini akan dilakukan ijin survei yang ditujukan kepada ketua Karang Taruna Pemuda Mandiri untuk dilakukan survei dan wawancara kepada anggota mitra. (2) Sosialisasi Program: sebelum dilaksanakannya pelatihan desain grafis CorelDRAW, terlebih dahulu dilakukan sosialisasi kepada para anggota mitra tentang proses dan manfaat pelaksanaan dari program pengabdian masyarakat ini, sehingga akan dapat menggerakkan antusias para anggota mitra untuk mau bergabung melaksanakan program pengabdian yang telah direncanakan. (3) Pelatihan: Pelatihan yang akan dilaksanakan meliputi materi kegunaan desain grafis CorelDRAW dalam kegiatan karang taruna, pendampingan penggunaan desain grafis CorelDRAW dalam kegiatan karang taruna.

\section{METODE PELAKSANAAN}

Kegiatan Pelatihan desain grafis CorelDRAW dalam kegiatan karang taruna diadakan bertempat Saung Inspirasi RW 003 Kelurahan Rejomulyo dan dihadiri 15 Peserta. Program pengabdian pelatihan menggunakan beberapa metode sebagai berikut: (1) Metode Ceramah, untuk memberikan informasi materi kegunaan keterampilan desain grafis CorelDRAW dalam kegiatan karang taruna dan materi penggunaan aplikasi CorelDRAW, (2) Metode praktek, untuk peserta pelatihan mendapatkan pengalaman langsung dalam tata cara penggunakan aplikasi CorelDRAW. (3) Metode tanya jawab dan diskusi, untuk merespon pertanyaan dari peserta pelatihan dan mengukur sejauh mana pemahaman dari peserta setelah metode ceramahdan selama metode praktek dilakukan oleh tim pengabdi, serta untuk bersama-sama melakukan dialog mengenai cara penggunakan aplikasi CorelDRAW.

\section{HASIL, PEMBAHASAN, DAN DAMPAK}

\section{Sosialisasi Program Pengabdian}

Pelatihan desain grafis CorelDRAW diawali dengan melakukan survei dan wawancara kepada ketua Karang Truna Pemuda Mandiri dan beberapa anggota. Sekaligus memberikan sosialisasi tentang program pengabdian pada hari Rabu, 11 Maret 2020. Setelah sepakat dengan program pengabdian kemudian menentukan waktu untuk melaksanakan kegiatan pelatihan 
desain grafis CorelDRAW. Pada kegiatan ini tim pengabdi menjelaskan program pelatihan yang akan dilakukan pada pertemuan berikutnya. Kegiatan ini ditargetkan untuk memberikan pemahaman dan keikutsertaan anggota mitra program pelatihan desain grafis CorelDRAW pada pertemuan berikutnya.

\section{Pelatihan Desain Grafis CorelDRAW}

Kegiatan pelatihan dilaksanakan pada tanggal 15 Maret 2020 di Saung Inspirasi RW 003 Kelurahan Rejomulyo Kecamatan Metro Selatan Kota Metro. Peserta pelatihan yang hadir merupakan perwakilan anggota dan ketua Karang Taruna Pemuda Mandiri Rejomulyo. Anggota Karang Taruna Pemuda Mandiri mayoritas adalah pemuda yang masih produktif. Dengan memberdayakan pengurus Karang Taruna Pemuda Mandiri diharapkan dapat memajukan generasi pemuda dibawah organisasi karang taruna yang mampu meningkatkan keteramppilan dibidang desain grafis CorelDRAW.

Susunan acara kegiatan pelatihan desain grafis CorelDRAW sebagai berikut: a) Pembukaan, b) Sambutan ketua tim pengabdi, c) Penjelasan materi pentingnya desain grafis CorelDRAW dalam berbagai kegiatan Karang Taruna serta pengenalan aplikasi CorelDRAW,

d) Praktek pembuatan desain pada aplikasi CorelDRAW, pengenalan menu-menu, cara membranding, desain, CorelDRAW hingga sampai praktek pembuatan desain pamflet e) Penutup dengan foto bersama antara mitra dengan, pemateri dan tim pengabdi dari Universitas Muhammadiyah Metro.

Ilmu desain grafis untuk memulai CorelDraw untuk pemula berisi pengenalan dan panduan dasar dalam belajar komputer desain. Sebelum memulainya tutorial CorelDraw akan lebih baik jika kita mengetahui apa saja yang terkandung didalamnya. Coreldraw adalah pengolah Vektor berupa garis dan bidang yang diolah berdasarkan pengaturanpengaturan angka-angka vector (Rini, 2017). Begitu juga dalam pelatihan ini juda dimulai dari mempelajari mengenai desain grafis kemudian baru masuk pada aplikasi CorelDRAW. Sehingga sebelum peserta melakukan praktik aplikasi CorelDRAW, peserta dipaparkan materi mengenai desain grafis. 


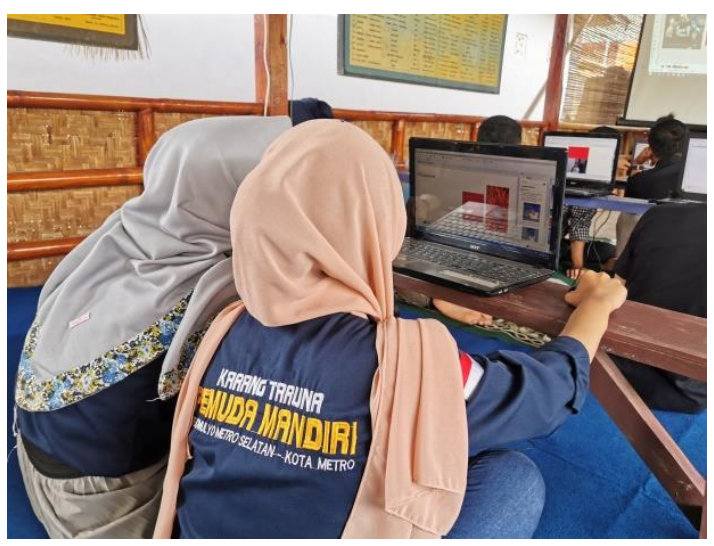

Gambar 1. Praktek Aplikasi CorelDRAW

Dalam pelatihan ini mengutamakan praktik langsung, sehingga waktu banyak digunakan untuk praktik agar kreatifitas dalam desain grafis dapat secara langsung teraplikasi. Kemampuan peserta dalama memahami desain grafis peserta cukup baik, ini ditunjukan dengan kemampuan peserta dalam mengingat jenis dan letak tools yang digunakan sesuai dengan kebutuhan. Kemudian kemampuan teknis praktik peserta masih memerlukan latihan secara rutin terutama dalam kemampuan memodifikasi bentuk umum yang telah tersedia dari aplikasi menjadi bentuk-bentuk yang sesuai dengan keinginan.

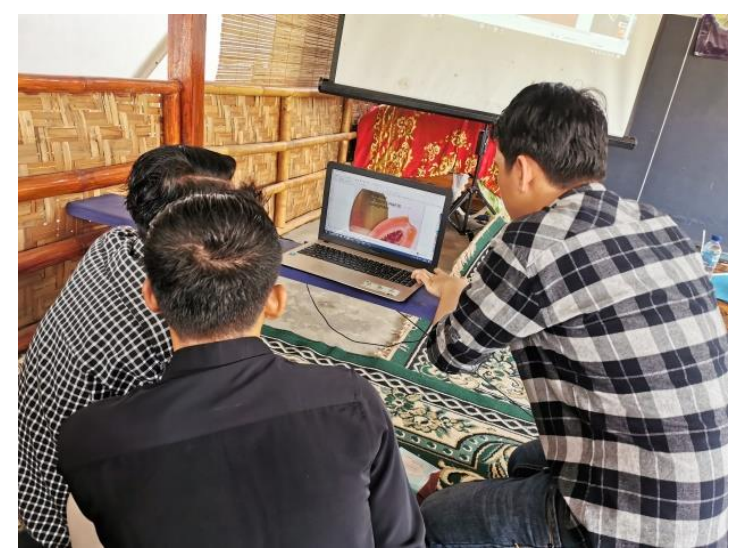

Gambar 2. Pendampingan Praktik Aplikasi CorelDRAW

Beberapa peserta sering mengalami kesulitan dalam praktik, misalnya dalam membuat objek yang diinginkan. Peserta juga masih kaku dalam menggerakkan kursor dan mouse sehingga ini menjadi kendala dalam praktik dan memakan waktu lebih panjang. Dalam hal ini tim pengabdi dan pemateri membimbing peserta yang mengalami kesulitan tersebut. Sehingga peserta terbantu dan lebih cepat dalam proses praktik.

Pelatihan ini mengembangkan kemampuan pengurus karang taruna dalam desain grafis dengan aplikasi CorelDraw ini bertujuan untuk bakat kreatifitas dalam bidang komputer, 
khususnya pada bidang desain grafis, sehingga menghasilkan produk berupa poster. Kemampuan peserta dalam memahami desain grafis peserta cukup baik, ini ditunjukan dengan kemampuan peserta dalam mengingat jenis dan letak tools yang digunakan sesuai dengan kebutuhan. Kemudian kemampuan teknis praktik peserta masih memerlukan latihan secara rutin terutama dalam kemampuan memodifikasi bentuk umum yang telah tersedia dari aplikasi menjadi bentuk-bentuk yang sesuai dengan keinginan.

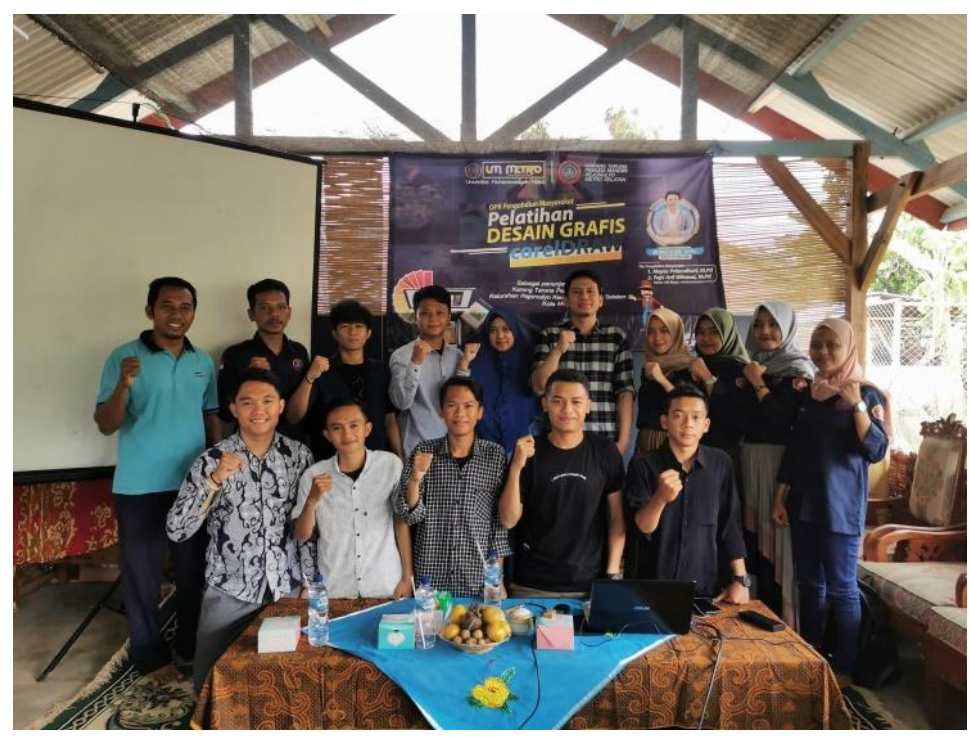

Gambar 2. Foto Bersama Peserta Pelatihan

\section{SIMPULAN}

Berdasarkan hasil dan pembahasan mengenai pelatihan desain grafis CorelDRAW dapat disimpulkan bahwa mitra pemuda karang taruna Pemuda Mandiri Rejomulyo mampu meningkatkan kreatifitas dalam bidang desain grafis CorelDRAW. Mitra juga telah berhasil memiliki kemampuan mendesain menggunakan aplikasi CorelDRAW, serta mengetahui tips dan trik membuat desain grafis.

\section{UCAPAN TERIMAKASIH}

Tim pengabdi mengucapkan terima kasih kepada Lembaga Pengabdian Pada Masyarakat (LPPM) Universitas Muhammadiyah Metro yang telah mendanai kegiatan pengabdian ini sehingga terlaksana dengan baik. Selain itu, pengabdi juga mengucapkan terima kasih kepada mitra karang taruna Pemuda Mandiri Kelurahan Rejomulyo Kecamatan Metro Selatan Kota Metro yang telah memberikan kesempatan untuk melaksanakan kegiatan pengabdian ini. 


\section{DAFTAR PUSTAKA}

Endah, Auliya. 2018. Peningkatan Kreativitas Siswa Sekolah Menengah Pertama Dengan Pelatihan Corel Draw. Jurnal Pengabdian Dharma Bakti Vol.1, No. 2, Agustus 2018

Mayang, dkk. 2016. Pelatihan Design Grafis CorelDRAW X4 Sebagai Penunjang Pembelajaran Bagi Guru Pada SMAN 1 Sungai Tabuk. Jurnal Al-Ikhlas Vol. 2 No. 1.

Rais, dkk. 2018. Peningkatan Keterampilan Multimedia CorelDRAW Di SMK Assalafiyah Kota Tegal. Jurnal Abdimas PHB Vol 1 No. 1.

Republik Indonesia. Peraturan Menteri Dalam Negeri Nomor 5 Tahun 2007. Pedoman Penataan Lembaga Kemasyarakatan Karang Taruna.

Ridwan, dkk. 2020. Peningkatan Desain Grafis Untuk Meningkatkan Kreatifitas Dan Menambah Daya Saing Masyarakat Kecamatan Pasar Minggu Jakarta Selatan. Suluh: Jurnal Abdimas Vol. 2 No. 1

Rini. 2017. Pelatihan Desain Grafis Untuk Perangkat Desa Dalam Rangka Peningkatan Sdm Di Desa Ngawonggo Kecamatan Tajinan Kab. Malang. Jurnal ABDIMAS Unmer Malang Vol. 2, Nomor 1.

Rini, Dodit. 2018. Pelatihan Desain Grafis Dan Fotonovela Untuk Warga Desa Ngembal Kec. Wajak Kab. Malang. Jurnal Kumawula, Vol. 1, No. 3.

Sony. 2019. Pelatihan Desain Grafis dan Multimediadi Sekolah Menengah Kejuruhan Persatuan Guru Republik IndonesiaBanyuputih Situbondo. JPM (Jurnal Pemberdayaan Masyarakat) Vol. 4No. 1

Wahyudi, Anggri. 2020. Pelatihan Corel Draw Untuk Perangkat Desa Ngawonggo Kecamatan Tajinan. Jurnal Martabe Volume 3 Nomor 1. 